\title{
Review
}

Neuro[mmunoModulation

\section{The Effects of Neurotrophins and the Neuropeptides VIP and PACAP on HIV-1 Infection: Histories with Opposite Ends}

\author{
Thiago Moreno L. Souza ${ }^{a} \quad$ Jairo R. Temerozo ${ }^{b}$ Elizabeth Giestal-de-Araujo ${ }^{c}$ \\ Dumith Chequer Bou-Habib ${ }^{b}$

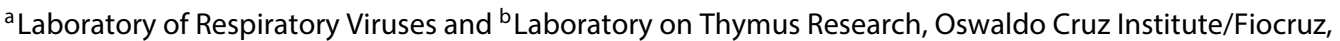 \\ Rio de Janeiro, and ' $\mathrm{Hertha}$ Meyer Laboratory of Tissue Culture, Fluminense Federal University, Niteroi, Brazil
}

\section{Key Words}

Human immunodeficiency virus . Nerve growth factor .

Neuropeptides · Neurotrophins · Pituitary adenylate

cyclase-activating peptide $\cdot$ Vasoactive intestinal peptide

\begin{abstract}
The nerve growth factor (NGF) and other neurotrophins, and the neuropeptides vasoactive intestinal peptide (VIP) and pituitary adenylate cyclase-activating peptide (PACAP) are largely present in human tissue and can exert modulatory activities on nervous, endocrine and immune system functions. NGF, VIP and PACAP receptors are expressed systemically in organisms, and thus these mediators exhibit pleiotropic natures. The human immunodeficiency virus type 1 (HIV-1), the causal agent of the acquired immunodeficiency syndrome (AIDS), infects immune cells, and its replication is modulated by a number of endogenous factors that interact with HIV-1-infected cells. NGF, VIP and PACAP can also affect HIV-1 virus particle production upon binding to their receptors on the membranes of infected cells, which triggers cell signaling pathways that modify the HIV-1 replicative cycle. These molecules exert opposite effects on HIV-1 replication, as NGF and other neurotrophins enhance and VIP and PACAP reduce viral production in HIV-1-infected human primary
\end{abstract}

macrophages. The understanding of AIDS pathogenesis should consider the mechanisms by which the replication of HIV-1, a pathogen that causes chronic morbidity, is influenced by neurotrophins, VIP and PACAP, i.e. molecules that exert a broad spectrum of physiological activities on the neuroimmunoendocrine axis. In this review, we will present the main effects of these two groups of mediators on the HIV-1 replicative cycle, as well as the mechanisms that underlie their abilities to modulate HIV-1 production in infected immune cells, and discuss the possible repercussion of the cross talk between NGF and both neuropeptides on the pathogenesis of HIV-1 infection.

ㄷ) 2014 S. Karger AG, Basel

\section{Introduction}

Infection by human immunodeficiency virus type 1 (HIV-1), the etiological agent of the acquired immunodeficiency syndrome (AIDS), is characterized by persistent viral replication in lymphoid tissue and a continuous

Thiago Moreno L. Souza and Jairo R. Temerozo contributed equally to this work.

\section{KARGER}

E-Mail karger@karger.com

www.karger.com/nim
(C) 2014 S. Karger AG, Base

1021-7401/14/0215-0268\$39.50/0
Dumith Chequer Bou-Habib

Laboratório de Pesquisas sobre o Timo

Instituto Oswaldo Cruz/Fiocruz, Av. Brasil 4365, Manguinhos

Pav. Leonidas Deane/510, Rio de Janeiro, RJ 21040-360 (Brazil)

E-Maildumith@ioc.fiocruz.br, dumith@pq.cnpq.br 
decline in CD4+ T cell numbers. In the absence of antiretroviral treatment, HIV-1 infection induces progressive deterioration in immune system function, promotes central nervous system (CNS) degeneration, increases host susceptibility to opportunistic infections and leads to severe immunodeficiency [1].

HIV-1 infects and replicates in CD4+ T lymphocytes, macrophages, dendritic cells and in CNS microglial cells. HIV-1 uses the CD4 molecule as the main cellular receptor to penetrate into the target cells; HIV-1 also requires a coreceptor, either CCR5 or CXCR4 (receptors for $\beta$ - or $\alpha$-chemokines, respectively) [2]. Several conditions or endogenous factors are well known to modulate viral replication in infected cells, and these factors can affect the viral load in HIV-1-infected individuals. For example, chronic immune system activation favors HIV-1 replication and is associated with accelerated infection progression to the clinical symptoms of immune deficiency that are typical of AIDS [3]. Likewise, many natural molecules can promote enhanced HIV-1 production or induce the opposite effect by diminishing HIV-1 growth in infected cells [4].

Neurotrophic factors are critical molecules for nervous system development and neuronal cell survival, and play important roles during the adult life. In mammals, the neurotrophin family includes nerve growth factor (NGF), brain-derived neurotrophic factor (BDNF), neurotrophin (NT)-3 and NT-4 and NT-5 [5]. NGF was the first identified neurotrophic factor, following the pioneering and seminal studies of Levi-Montalcini and Hamburger, who described in the early 1950s that NGF was a trophic and neuritogenic factor for dorsal root ganglion and sympathetic neurons [6]. The effects of NTs are not restricted to the nervous system, as they also regulate immune cell functions, modulate inflammatory responses and are associated with many other peripheral physiological effects $[7,8]$.

The neuropeptides vasoactive intestinal peptide (VIP) and pituitary adenylate cyclase-activating peptide (PACAP) are expressed in both the central and peripheral nervous system and are widely distributed throughout the organism [9]. VIP and PACAP share structural similarities with each other and with peptides from the secretin/ glucagon peptide family, and both exert a large range of biological effects that target the nervous, endocrine, gastrointestinal, circulatory and immune systems [9]. Both neuropeptides can act as natural anti-inflammatory agents due to their ability to inhibit the activity or production of several proinflammatory molecules and to stimulate the production of anti-inflammatory mediators $[9,10]$.

Effect of NTs and Neuropeptides on HIV-1 Infection
Considering that HIV-1/host cell interactions and viral replication are influenced by numerous endogenous molecules with diverse biochemical natures and physiological roles, it is relevant to understand how HIV-1 infection is affected by NTs and the neuropeptides VIP and PACAP, which are endowed with a wide range of physiological activities. In this review, we will describe the main effects of these molecules on HIV-1 replication and discuss the mechanisms that underlie their abilities to modulate HIV-1 growth in infected immune cells, as well as the possible repercussion of the cross talk between NGF and both neuropeptides on the pathogenesis of HIV-1 infection.

\section{HIV-1 Infection}

According to the United Nations Program on HIV/ AIDS, approximately 34 million people worldwide are infected with HIV [11]. HIV belongs to the Retroviridae family, in which genomic RNA is reverse transcribed to DNA by the retrovirus-typical enzyme reverse transcriptase, and to the Lentivirinae subfamily, which is associated with persistent infections and long clinical latency periods [12]. Regarding viral genetic diversity, HIV isolates have been classified into two types, HIV-1 and HIV2 , which have been further subclassified into groups and subtypes [see ref. 12 for more information on this subject]. Thereafter, in this review, we will refer to HIV-1, which is responsible for the worldwide pandemic and induces a more profound immunosuppression than HIV-2 [12].

The HIV-1 replicative cycle begins when the virus envelope glycoprotein gp120 interacts with its receptors on the cell membrane, followed by the fusion of the cell membrane with the viral envelope and the release of the viral nucleocapsid into the cell cytoplasm. Next, the viral RNA genome is transcribed by reverse transcriptase into double-stranded proviral DNA, which is then integrated into the host cell genome by the viral enzyme integrase. In response to a number of stimuli, the viral DNA is transcribed to produce new virus particles that are subsequently released into the extracellular environment via budding from the cell membrane [for a review of the HIV-1 replicative cycle, see ref. 13-16]. HIV-1 isolates are phenotypically classified according to the chemokine receptor to which they preferentially bind on the cell membrane during the infection process. Thus, the isolates are designated as R5-tropic, X4-tropic or R5X4 dual-tropic viruses, according to their interactions with CCR5,

Neuroimmunomodulation 2014;21:268-282 
CXCR4 or with either receptor, respectively. Individuals who carry a homozygous mutant allele with a 32-base pair deletion in the CCR 5 gene $(c c r 5 \Delta 32)$, which encodes a truncated protein that is not expressed in the cell membrane, are refractory to infection by R5-tropic HIV-1 isolates [17].

During the acute HIV-1 infection phase, due to viral propagation throughout the tissues, many viral reservoirs are established that consist mainly of memory CD4+ T cells and resident macrophages from the gastrointestinal lymphoid tissues (GALT) $[18,19]$. These reservoirs of HIV1-infected cells can sustain continuous viral replication for long periods of time, thus affecting HIV-1 evolution and genetic diversity in different compartments of the human body [20]. Today, identification of the mechanisms that underlie HIV-1 reservoir survival and maintenance is generally believed to be critical to the search for new and effective anti-HIV-1 therapeutic strategies [21-23].

One particular HIV-1 reservoir established early after seroconversion is found in the CNS and represents a constant threat to neuronal cells $[24,25]$. In fact, studies of postmortem nervous tissues or animal models have shown that brain macrophages and microglia are permissive to productive HIV-1 and simian immunodeficiency virus (SIV) infections and can become viral reservoirs [26-28]. Persistent HIV-1 replication may occur even in the CNS of individuals with undetectable viral loads in the peripheral blood due to antiretroviral therapy [29]. Although HIV-1 does not replicate in neurons, its productive infection in other cell types leads to the release of neurotoxic viral proteins, such as Tat, Nef, Vpr and gp120 [30-33]. These viral proteins induce neuronal apoptosis and affect axonal projections to their targets, impairing neuronal plasticity and function [34-41]. Moreover, the chronic immune activation due to HIV-1 proteins and other antigens (as discussed below) results in a persistent proinflammatory condition in the CNS with concomitant homing of anti-HIV-1-specific CD8+ T lymphocytes to this site, which may accentuate the cell death [42]. The nervous tissue damage during the course of HIV-1 infection is also aggravated by the systemic increase in proinflammatory cytokines, such as tumor necrosis factor (TNF)- $\alpha$, interleukin (IL)- $1 \beta$ and IL- 6 , which induce oxidative stress in neuronal cells and modify the permeability of the blood-brain barrier [43-46].

Before the introduction of highly active antiretroviral therapy, an elevated number of HIV-1-infected patients presented a panel of severe neurocognitive symptoms that were designated as HIV-1-associated dementia, the onset of which correlated with the viral load and infection time course [47]. Today, despite better HIV-1 infection management, neurocognitive disorders continue to be diagnosed, although these conditions may be dissociated from viral load levels and CD4+ T cell counts. Since highly active antiretroviral therapy allows HIV-1-infected individuals to live longer, age-associated neurocognitive disorders converge with HIV-1-persistent replication in the CNS reservoirs, resulting in an increased risk factor for injuries in this compartment [48]. In contrast to the era before highly active antiretroviral therapy, the newly recognized CNS impairments present as asymptomatic forms or with only mild symptoms [49]. These dysfunctions are now grouped as asymptomatic neurocognitive impairments or mild neurocognitive disorders that, together with HIV-1-associated dementia, comprise the complex designated as HIV-1-associated neurocognitive disorders [50]. Neurocognitive injuries can be recognized by a collection of signs, such as behavioral alterations, forgetfulness, nerve pain, motor control impairment, headache and depression, which are associated with anatomical alterations in the brain [50].

Several conditions contribute to maintain or increase viral loads in HIV-1-infected individuals. For example, persistent immune system activation due to HIV-1 proteins, co-infecting agents or microbial products translocated from the intestinal lumen favors HIV-1 replication and can accelerate infection progression from an asymptomatic state to the clinical symptoms of immunosuppression typical of AIDS [51]. Chronic immune system stimulation elevates the number of HIV-1-permissive cells, promotes a more rapid turnover of T cells and eventually provokes a severe loss of CD4+ T lymphocytes, which is the hallmark of HIV-1 infection and AIDS [51]. The degree of immune system activation has now been considered the best predictor of HIV-1 disease progression, and decreased viral loads in HIV-1-infected patients who receive antiretroviral drugs are associated with steady reductions in systemic immune activation levels [52]. Many experimental studies have also consistently shown that endogenous molecules can promote enhanced HIV-1 production, including the cytokines TNF- $\alpha$, IL$1 \beta$, IL-6, macrophage migration inhibitory factor and NGF, whereas other natural soluble mediators can induce the opposite effect by diminishing HIV-1 growth, including the cytokines IL-10, IL-27 and interferon (IFN) $\alpha / \beta$, the $\beta$-chemokines CCL3, CCL4 and CCL5, and the neuropeptides VIP and PACAP [53-61].

The final outcome of an HIV-1-productive infection can also depend on the balance between innate natural factors that can limit viral replication or release and 
HIV-1 accessory genes that neutralize the antiretroviral effects of these natural restriction factors [62]. Lately, some IFN-stimulated products have been described as intrinsic restriction factors against HIV-1 replication. For example, the cytidine-deaminase enzymes apolipoprotein B mRNA-editing enzyme catalytic polypeptidelike (APOBEC) $3 \mathrm{G} / 3 \mathrm{~F} / 3 \mathrm{~A}$ are incorporated into virus particles, where they induce guanosine $\rightarrow$ adenosine mutations in the nascent viral DNA during RNA reverse transcription [63]. These hypermutations generate defective virions that are incapable of producing new rounds of successful infections [63]. APOBEC proteins can also inhibit HIV-1 independently of their catalytic activity, as they bind to viral DNA and prevent its processing by the HIV-1 enzyme integrase, thus reducing the integration of HIV-1 DNA to the host cell genome $[64,65]$. The APOBEC anti-HIV-1 effects are antagonized by the viral protein Vif through the induction of APOBEC degradation [63]. The bone marrow stromal cell antigen 2 protein (BST2/CD317; also known as tetherin) restricts the budding of mature HIV-1 viral particles by retaining the virions in the membrane of the infected cell [66]. This anti-HIV-1 activity is counterbalanced by the virus proteins $\mathrm{Vpu}$ and $\mathrm{Nef}[67,68]$. Three members of the IFN-induced transmembrane family of proteins (IFITMs) also naturally hinder HIV-1 replication by mechanisms not yet clearly defined, although recent findings suggest that these factors interfere with the production of viral proteins $[69,70]$. It is not known how HIV-1 counterbalances the antiviral effects of IFITMs. In dendritic cells and other myeloid-derived cells, the sterile a motif domain and HD domain-containing protein 1 (SAMHD1) restricts HIV-1 and HIV-2 replication through the hydrolysis of deoxynucleoside triphosphates into deoxynucleosides and triphosphates [71], therefore depleting the deoxynucleoside triphosphate pool and diminishing the efficiency of both, HIV-1 RNA reverse transcription and provirus transcription. SAMHD1 has also a $3^{\prime}-5^{\prime}$ exonuclease activity [71-73], which possibly contributes for its anti-HIV-1 effects, which are counteracted by the HIV-2 protein Vpx through promoting SAMHD1 degradation. Macrophages and dendritic cells release much less HIV-1 particles than lymphocytes, which may be partially explained by the activity of viperin (also known as RSAD2), a cell membrane-interacting protein induced by viral infection and IFNs [74-76]. Viperin interferes with the virus budding process of various viruses, including HIV-1 [77-81], through inhibition of FPPS, an enzyme involved in the maintenance of lipid-raft and lipid-protein interaction/modification

Effect of NTs and Neuropeptides on HIV-1 Infection
$[79,82]$. It is not yet known how HIV-1 escapes from the viperin effects. Recently, a new IFN-stimulated HIV-1 restriction factor was identified, the myxovirus resistance 2 protein (MX2), which restricts both HIV-1 and simian immunodeficiency virus replication by blocking provirus integration in the cell genome, possibly by its interaction with the capsid region of the viral protein Gag [83].

\section{NGF, Other NTs and HIV-1 Infection}

NGF is the most studied NT and the one from which the most findings related to the role of neurotrophic factors in HIV-1 infection have been obtained. This molecule is synthesized as a 305-amino acid precursor protein and is cleaved to derive the mature 118-amino acid structure; the biologically active NGF molecule is formed as a dimer with subunits of approximately $13 \mathrm{kDa}[84,85]$. The signaling pathways activated by NGF depend on two distinct receptor types, tropomyosin-related kinase (Trk) and $\mathrm{p} 75^{\mathrm{NTR}}[84,85]$. Trk receptors belong to the tyrosine kinase group of receptors, and their activation promotes cell survival and differentiation $[84,85]$. NTs preferentially bind three Trk isoforms, such that NGF activates TrkA, BDNF and NT-4/NT-5 engage TrkB, and NT-3 binds TrkC $[84,85]$. Due to the existing homology between NGF and the other NTs and between the TrkA receptor and other receptor family members, a certain degree of promiscuity exists between the ligands and receptors; for example, NT-3 can also activate the TrkA and TrkB receptors [85]. The NGF-TrkA interaction promotes the dimerization and transphosphorylation of the TrkA tyrosine residues and triggers a signaling cascade that culminates in the differentiation and survival of several cell types [84]. Once phosphorylated, TrkA can activate other intracellular proteins such as nuclear factor (NF)- $\kappa \mathrm{B}$, phosphoinositide 3-kinase, protein kinases PKC and PKA and the mitogen-activated protein kinases (MAPKs) and modulate different signaling pathways [84-86].

The Trks and $\mathrm{p} 75^{\mathrm{NTR}}$ receptors can trigger either synergistic or antagonistic actions or function independently according to the target cell $[87,88]$. Similar to the TNF receptor superfamily, p $75^{\mathrm{NTR}}$ contains a death domain in its intracellular region [89]. The death domain mediates interactions with other cellular components that allow $\mathrm{p} 75^{\mathrm{NTR}}$ to regulate intracellular signaling events, such as $\mathrm{NF}-\kappa \mathrm{B}$, JNK and caspase activation, in response to NT ligation [90]. 
NTs play an important role in the establishment of the neuronal population throughout development [91, 92]. They are produced by nerve target cells and can determine axonal migration; neurons that assemble efficient synapses and retain NTs are more likely to survive [92]. In adult animals, cells continue to produce NTs and express NT receptors, suggesting that these neuromodulators contribute to internal homeostasis throughout the life of an organism $[93,94]$. Today, it is well known that the effects of NTs are not restricted to the central and peripheral nervous systems. In fact, these molecules affect neuroimmunoendocrine interactions by activating the hypothalamic-pituitary-adrenal axis and thus regulate inflammatory responses $[7,8,95]$. Increased serum NGF and corticosteroid levels are associated with chronic stress events, and NGF synthesis is induced by the cytokines IL-1, IL-6, TNF- $\alpha$ and transforming growth factor- $\beta$ during the course of an inflammatory reaction $[8,96]$. NGF regulates the immune system by promoting myeloid precursor growth and maturation, inducing $B$ and T lymphocyte proliferation and $\mathrm{B}$ cell differentiation into plasma cells, and stimulating immunoglobulin and eicosanoid production [97-101]. Following NGF treatment, $\mathrm{CD} 4+\mathrm{T}$ cells produce and release this NT, suggesting that NGF participates in lymphocyte survival and functioning $[102,103]$. NGF is also associated with neutrophil chemotaxis, mast cell degranulation and differentiation, and the induction of monocyte cytotoxic activity [104-107].

Some pathogens have established curious interactions with NTs. For example, human syncytial respiratory virus, the main causal agent of bronchiolitis in children up to 6 months old, stimulates the expression of NGF and its receptor $[108,109]$; herpes simplex virus (HSV-1), which can provoke mucocutaneous lesions, keratoconjunctivitis and encephalitis, establishes long latent periods in the trigeminal ganglia in an NGF-TrkA interaction-dependent fashion $[110,111]$; the protozoan parasite Trypanosoma cruzi, the etiological agent of Chagas disease, expresses a transsialidase that mimics mammalian NTs and is named parasite-derived neurotrophic factor due to its ability to engage Trk receptors and promote host cell survival $[112,113]$, and the NTs NGF, proNGF and BDNF facilitate HIV-1 replication in human monocyte-derived macrophages, as we will discuss further in this review.

The initial suggestions that NTs could interfere in the HIV-1 replicative cycle came from independent studies performed in the mid-1990s. Ensoli et al. [114], using a model that might be representative of pediatric infection as a consequence of vertical transmission, observed that NGF can stimulate HIV-1 replication in neuroblastic and embryonic glial cell lines, which are immature cells of the CNS. Recio and Aranda [115], by means of transfecting HIV-1 long-terminal repeats in NGF-induced neuronaldifferentiated PC12 pheochromocytoma cells, showed that this NT promoted a strong activation of HIV-1 gene transcription in a Ras/Raf-dependent fashion. Although defining studies, the actual significance of their findings could be limited due to the evidence that neurons are refractory to HIV-1 productive infection. In the late 1990s, Levi-Montalcini and her group performed their investigation using human primary macrophages, providing a more comprehensible understanding of how NGF affects the HIV-1 interaction with a naturally virus-producing cell. They demonstrated that HIV-1-infected macrophages expressed elevated levels of NGF and the TrkA receptor, and that anti-NGF neutralizing antibodies reduced HIV-1 production and induced macrophage apoptosis [116]. In summary, this study unequivocally showed that NGF could act as an autocrine survival factor for HIV-1-infected macrophages, but left open the hypothesis that NGF could also directly facilitate HIV-1 replication in primary macrophages.

In a more recent investigation, we reported that NGF (as well as BDNF and proNGF) enhanced HIV-1 replication in human primary monocyte-derived macrophages via PKC, NF- $\kappa B$, extracellular signal-regulated kinase and p38 kinase-dependent signaling pathways that were triggered by the NGF-TrkA interaction [57]. We also reported that NGF increased HIV-1 proviral DNA transcription, eventually leading to increased HIV-1 production in macrophages. NGF also inhibited the synthesis of the endogenous HIV-1 restriction factor APOBEC3G (A3G), thus reducing $G \rightarrow$ A hypermutation events in the viral genome and retaining viral fitness.

Taken together, these studies revealed that NGF is not only an essential factor for HIV-1-infected macrophage survival and an enhancer of viral transcription and replication, but is also a critical mediator that permits cellular HIV-1 reservoirs to produce virus particles with a preserved replicative capacity and infectivity. These findings are summarized in figure 1 . Samah et al. $[117,118]$, however, described opposite results by observing not only that NGF failed to facilitate HIV-1 replication in macrophages, but also that HIV-1 production decreased in a NGF-treated monocyte population that migrated in response to the chemokine CXCL12. NGF, which is produced by perivascular macrophages and multinucleated giant cells during HIV-1-induced encephalitis, stimulates monocytes to express CXCR4, the receptor for CXCL12. Thus, although their and our studies differ in the culture 


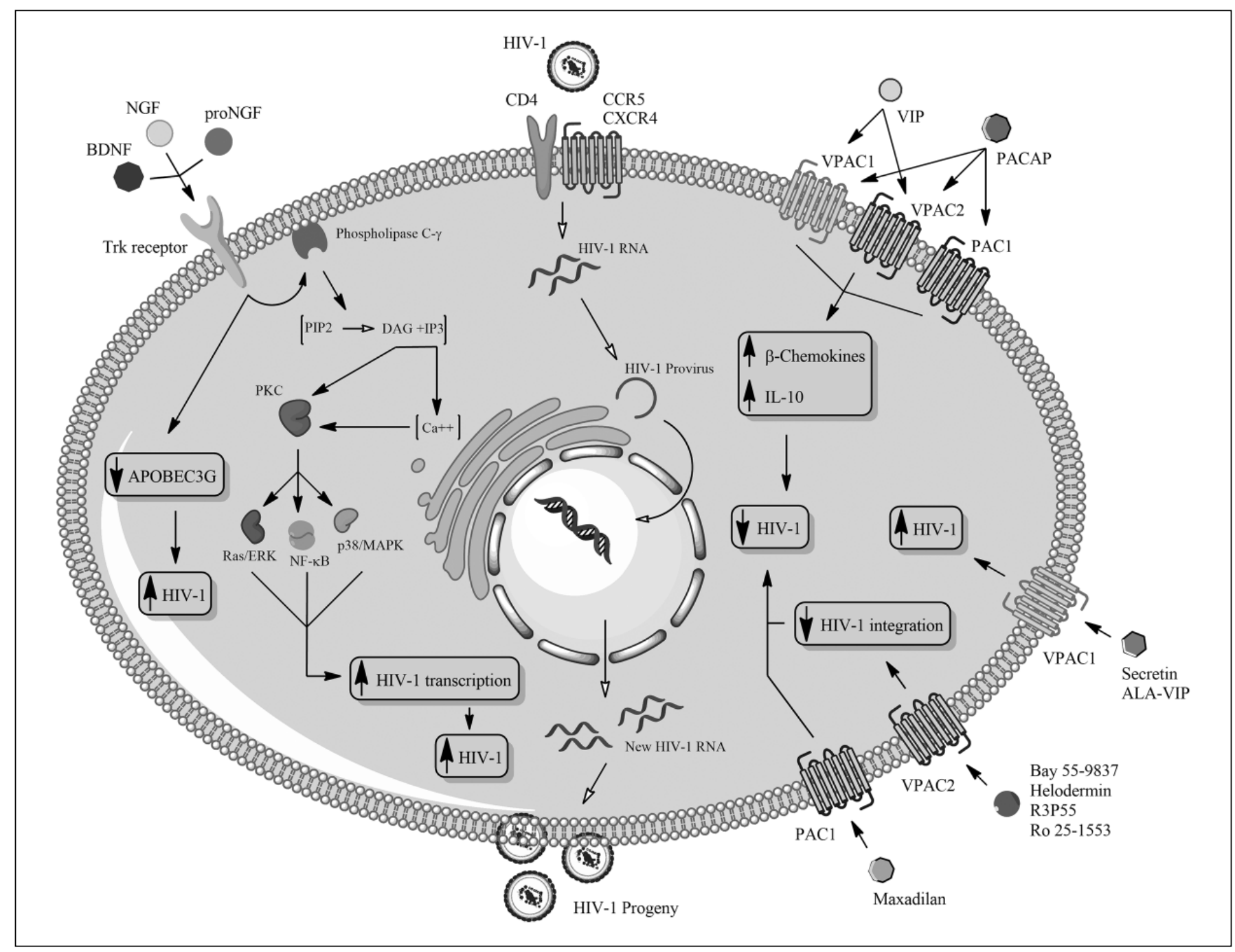

Fig. 1. NTs and the neuropeptides VIP and PACAP present opposing effects on HIV-1 replication. The center of the figure shows a simplified model of the HIV-1 replicative cycle (as described in main text). NTs (left side) enhance HIV-1 replication in macrophages by means of Trk receptor activation and by triggering multiple signaling pathways that culminate with concomitant increases in viral transcription and production. The NGF-mediated downregulation of APOBEC3G synthesis and activity allows the production of HIV-1 virions with preserved replicative capacity. The neuropeptides VIP and PACAP (right side) inhibit HIV-1 production in macrophages through upregulation of cell produc-

conditions, activating factors added to cells and the time point at which NGF was added to monocytes or macrophages with respect to HIV-1 infection, they are to some extent complementary, as HIV-1-infected macrophages are constantly exposed to numerous stimuli and respond according to the mediators present in the cell microenvironment.

Effect of NTs and Neuropeptides on HIV-1 Infection tion of $\beta$-chemokines and IL-10, after engaging VPAC1/2 receptors by VIP, and VPAC $1 / 2$ and PAC 1 by PACAP. In macrophages and CD4+ T cells, the sole activation of VPAC2 (Bay 55-9837 [200], helodermin [201], R3P55 [202] and RO 25-1553 [203]) and PAC1 (maxadilan [182]) by specific agonists also decreases HIV-1 replication, whereas ligation of VPAC1 only (secretin [180] and ALA-VIP [181]) results in an opposite effect. PIP2 = Phosphatidylinositol 4,5-biphosphate; DAG = diacylglycerol; IP3 = inositol 1,4,5-triphosphate; Ras/ERK = rat sarcoma/extracellular signalregulated kinase).

The HIV-1 proteins Tat, Nef, gp120 and Vpr can cause neuronal loss, either due to proapoptotic stimuli or by impairing axonal projections and neuronal plasticity/ function, especially in sympathetic neurons [34-41]. NT signaling through Trk receptors has been associated with anti-apoptotic activity and with enhancement of synaptic connections, and many works, using different cellular

Neuroimmunomodulation 2014;21:268-282 
models and treatment strategies, have shown that NGF and BDNF are able to recover neuronal plasticity impaired by HIV-1 proteins and to rescue neuronal cells from HIV-1-induced apoptosis [119-122]. Clinical trials in which NGF was used as a treatment for HIV-associated distal sensory polyneuropathy showed that this therapy was safe and well tolerated, and significantly relieved the pain symptoms. Nevertheless, no amelioration of neuropathy severity was recorded $[123,124]$.

Although the results of such studies point to neuroprotective effects of both NTs with obvious benefits for patients with AIDS-associated dementia, the therapeutic use of NGF or BDNF should be examined carefully due to the enhancer activities of NGF and other NTs on HIV-1 replication $[57,125]$. Thus, it is critical to identify the ideal balance between the neuroprotective and the HIV1-productive infection-promoting effects of NTs.

\section{The Neuropeptides VIP and PACAP and HIV-1 Infection}

VIP, a 28-amino acid molecule that was initially identified in the swine small intestine, is endowed with numerous biological effects and can cause systemic vasodilation, increased cardiac output, hypotension and hyperglycemia [126]. VIP also modulates the functions of the immune system and the central and peripheral nervous systems, and acts as an endogenous anti-inflammatory agent $[127,128]$. PACAP was first isolated from the ovine hypothalamus and was named for its ability to activate the enzyme adenylate cyclase and induce the production of cyclic adenosine monophosphate in anterior pituitary cells [129]. PACAP shares $68 \%$ amino acid sequence homology with VIP and exists in two isoforms, which are designated PACAP-27 and PACAP-38 according to their amino acid numbers [130-136]. PACAP (predominantly PACAP-38) is widely expressed in the CNS and peripheral tissues, and can play a large number of modulatory roles in the nervous tissue and the immune system [10, 137].

VIP and PACAP share cellular receptors, which are named VPAC1, VPAC2 and PAC1. PAC1 recognizes both PACAP isoforms with high affinity and VIP with low affinity, whereas VPAC1 and VPAC2 are engaged with similarly high affinities by both neuropeptides [138141]. Thus, VPAC1 and VPAC2 can mediate the effects of VIP and PACAP with the same efficiency, whereas $\mathrm{PAC1}$ is activated primarily by PACAP. These three receptors belong to the $\mathrm{G}$ protein-coupled receptor com- plex and thus present the typical structure of seven transmembrane domains joined by intra- and extracellular loops [140, 142-144]. VPAC1 and VPAC2 can also present an uncommon five transmembrane structure derived from alternative splicing, and PAC1 can also express a high number of spliced isoforms; all these isoforms are related to tissue/cell expression and differential signaling activation $[145,146]$. VPAC1, VPAC2 and PAC1 are widely distributed in the tissues and, within the immune system, VPAC1 and VPAC2 are expressed in lymphocytes, macrophages and dendritic cells, whereas PAC1 expression is limited to macrophages [147-152]. No systematic studies have explored the expression of these receptors in other immune cells. The binding of VIP and PACAP to their receptors activates signaling pathways that involve cyclic adenosine monophosphate/PKA and diacylglycerol/inositol 1,4,5-triphosphate/PKC that, in turn, can trigger the activation of other signaling cascade proteins, such as phosphoinositide 3-kinase, Src, MAPKs, Jak/STAT and NF- $\kappa B$ [153].

VIP and PACAP are produced and expressed in the central and peripheral nervous systems and in many other sites, including the gastrointestinal and urinary tracts and glandular tissues $[154,155]$. Both peptides are found in lymphoid tissues (e.g. thymus and spleen), in which thymocytes and CD4+ T helper (Th) 2 and CD8+ T lymphocytes are their main sources [132, 149, 156, 157]. VIP and PACAP regulate metabolic and endocrine activities and gastrointestinal tract functioning, and act as immunomodulatory and anti-inflammatory agents $[127,128$, 137]. These peptides participate in neural development and exert neuroprotective effects due to their ability to protect nervous tissue from injuries caused by a number of neurotoxic agents, such as ethanol, hydrogen peroxide and the HIV-1 gp120 [158-161].

One of the most prominent VIP and PACAP features concerns their role as natural anti-inflammatory agents, a property that has been experimentally well demonstrated in a variety of pathological conditions, including autoimmune and infectious diseases and the prevention of graft-versus-host disease $[162,163]$. The anti-inflammatory effects of VIP and PACAP derive from the ability of both neuropeptides to inhibit the activity or production of several proinflammatory molecules (such as chemokines, reactive oxygen and nitrogen species, IL-12, IL-6, IL- $1 \beta$, TNF- $\alpha$ and macrophage migration inhibitory factor), in addition to their capacity to stimulate the production of anti-inflammatory factors (e.g. IL-4 and IL-10) $[127,128,137]$. VIP and PACAP also participate in Th2 cell differentiation by inhibiting IL-12 production and in- 
ducing IL-4 and IL- 5 synthesis in macrophages and dendritic cells [127, 128, 137]. Moreover, VIP- or PACAPtreated macrophages stimulate $\mathrm{CD} 4+\mathrm{T}$ cells to produce the Th 2 cytokines IL- 4 and IL- 5 and inhibit the ability of the same cells to synthesize the Th1 cytokines IFN $-\gamma$ and IL-2 [127, 128, 137]. Additionally, dendritic cells differentiated in vitro in the presence of VIP exhibit tolerogenic properties, such as producing high amounts of IL-10 and inducing the differentiation of lymphocytes to $\mathrm{T}$ regulatory cells $[127,164]$.

VIP and PACAP also exert their anti-inflammatory effects by reducing cellular expression of the Toll-like receptors (TLRs), components of the innate immune system whose activation by pathogen molecules or endogenous ligands results in potent proinflammatory reactions $[165,166]$. VIP reduces TLR2 and TLR4 expression on CD4+ T cells in mice with experimental colitis and on the synovial cells of rheumatoid arthritis patients, and also downregulates TLR expression on macrophages activated by cognate TLR agonists [167-169]. PACAP reduces TLR2, TLR3, TLR4 and TLR6 expression, and also regulates MyD88 and NF- $\kappa B$ activation induced upon TLR engagement in models of renal ischemia and traumatic brain injury [170-172].

The small homology (five amino acids) between the peptide sequences of VIP and the variable region V2 of HIV-1 gp120 suggested that VIP and PACAP or their receptors might somehow participate in the pathogenesis of AIDS, based on the possibility that VIP could block HIV1 entry into target cells through direct interaction with the CD4 molecule $[173,174]$ or that gp 120 binding to VIP receptors could modify cellular processes related to the clinical course of HIV-1 infection [175, 176]. For example, some authors proposed that HIV-1 gp120 interaction with VIP receptors could be associated with HIV-1-induced neuron damage, through disrupting VIPergic networks and glial function [176]. This hypothesis was soon disregarded on the basis of the VIP inability to bind liver, intestinal and colonic tissues [177]. However, because of the current knowledge that VIP receptors present a plethora of isoforms, including those expressed in the CNS, the initial suggestion needs to be reevaluated.

Some experimental studies have addressed the role of VIP and PACAP in HIV-1 biology and viral production in target cells by using specific agonists of VPAC1, VPAC2 and PAC1 or native VIP and PACAP molecules. These investigations showed that, whereas productive HIV-1 infection can be facilitated by the sole activation of VPAC1, viral production is reduced in HIV-1-infected cells either following the engagement of VPAC2 or PAC1

Effect of NTs and Neuropeptides on HIV-1 Infection by specific ligands or when infected cells are treated with VIP and PACAP $[61,178,179]$. These effects are summarized in figure 1.

Initial studies reported that VPAC1 activation by secretin, a hormone peptide with affinity for VPAC1 [180], resulted in increased HIV-1 replication in CD4+ T cell lines and peripheral blood mononuclear cells [179], a phenomenon that was more recently found in primary monocyte-derived macrophages using ALA-VIP [61], a synthetic ligand of VPAC1 [181]. The sole VPAC1-specific engagement could occur by secretin or by the putative interaction of VPAC1 with the HIV-1 gp120 [173], but this last possibility needs to be tested. Together, these findings suggest that, in the absence of simultaneous VPAC2 and PAC1 activation, VPAC1 engagement sustains HIV-1 growth in immune cells. On the other hand, similar studies that used several specific ligands of the VPAC2 receptor (as shown in fig. 1) demonstrated that the isolated activation of this pathway reduced HIV-1 proviral DNA integration into the lymphocyte genome and also diminished viral growth in peripheral blood mononuclear cells, CD4+ T cell lines and in monocytederived macrophages [61, 178]. Likewise, reduced HIV-1 production was also found in HIV-1-infected macrophages after stimulation of PAC1 with maxadilan [61], a Lutzomyia longipalpis-derived specific ligand of this receptor [182]. We should note that, up to now, there is no evidence of natural sole activation of VPAC2 and PAC1 receptors in cells targeted by HIV-1.

The opposing effects on HIV-1 replication that are elicited by the isolated activation of these three receptors converge only to inhibit viral production when HIV1-infected cells are treated with VIP or PACAP, or with both neuropeptides simultaneously, meaning that under natural conditions, the engagement of VPAC1 and VPAC2 by VIP, or of both receptors plus PAC1 by PACAP, might ultimately reduce HIV-1 production in the target infected cells [61]. Interestingly, the combined use of specific agonists to mimic receptor ligation by natural neuropeptides resulted in reduced HIV-1 replication to a similar degree as the VIP- and PACAP-induced HIV-1 inhibition [61].

In addition to their ability to reduce HIV-1 replication, VIP and PACAP might also counteract other harmful effects caused by HIV-1 infection. In experimental studies, VIP restored the impaired cytotoxic function of natural killer cells that were exposed to the HIV-1 gp120, and both neuropeptides protected nervous tissue from gp120induced toxic effects $[160,161,183]$. Interestingly, the neuroprotection offered by VIP and PACAP is derived 
from their capacity to stimulate the synthesis and release of the $\beta$-chemokines CCL3 and CCL5, which, together with the cytokine IL-10, are associated with the ability of VIP and PACAP to inhibit HIV-1 replication [61, 160, 161].

An understanding of the effects resulting either from the individual activation of VPAC1, VPAC2 and PAC1, or from their engagement by the natural ligands VIP and PACAP on HIV-1 replication, is relevant to the development of anti-HIV-1 therapies based on VIP and PACAP, as well as alternative molecules that can block or activate the receptors to control HIV-1 propagation in tissues. Finally, it is important to indicate that additional studies should be conducted to evaluate the effects of VIP and PACAP, as well as those of receptor agonists, on viral production in primary CD4+ T lymphocytes, which are the most significantly affected cells in HIV-1-infected individuals.

\section{Cross Talk between NGF and VIP/PACAP and Possible Repercussions on HIV-1 Pathogenesis}

Several studies have demonstrated a cross-modulatory relationship between NGF and the neuropeptides VIP and PACAP at the levels of receptor gene transcription, release and transactivation. Additionally, the interdependent actions of NGF, VIP and PACAP have been described as responsible for the proliferation, differentiation and survival of nervous system cells, as well as the regulation of neurotransmitter release from the same cells.

In the scenario of a cross relationship between these mediators, many other effects can be quoted. For example, VIP promotes the survival of sympathetic neuroblasts during early developmental stages, in which it acts as a trophic agent for the cell progenitors before NGF production is initiated [184]; PACAP and NGF synergize to induce the postnatal differentiation and maturation of cholinergic neurons from the basal forebrain and to regulate the activity of these neurons through the induction of choline acetyl-transferase mRNA isoforms [185]; together, PACAP and NGF also promote the differentiation of neuronal classes and recruit transcriptional factors involved in the sympathetic-adrenal differentiation process $[186,187]$.

NGF, VIP and PACAP regulate each other, and thus form a complex functional network. Studies in animal models and tumor cell lines showed that NGF activates the PACAP and PAC1 promoters, indicating that NGF regulates $\mathrm{PACAP}$-stimulatory activity towards its target cells $[188,189]$. NGF is also a potential regulator of VIP, as it induces VIP expression in the rat suprachiasmatic nucleus during senescence and after chronic ethanol treatment (conditions in which the VIP levels are reduced in this site), thus restoring VIP production to initial levels $[190,191]$.

In addition, VIP and PACAP also regulate the expression of NGF and its receptors. For example, in a rat model of Parkinson's disease, VIP protects motor functions by inducing, among other mechanisms, NGF release from brain mast cells [192]; likewise, VIP enhances NGF gene expression and the release of both precursor and mature NGFs in human keratinocytes [193]. PACAP induces the expression of the NGF TrkA receptor via PAC1 activation [194] and can also transactivate the TrkA receptor in both neurons and monocytes [195-197], thus triggering TrkA receptor-related signaling pathways.

The ability to transactivate TrkA confers to PACAP the ability to mimic the trophic actions of NGF and thus maintain the integrity of the nervous tissue in the event of loss of neurotrophic primary factors. Studies of neurons also showed that PACAP-transactivated receptors are located mainly within the cell [195], thus highlighting the neurotrophic role of PACAP, which can act continuously, even during NT receptor turnover. Finally, both PACAP-38 and PACAP-27 have been described as VIP gene expression regulators [198, 199], suggesting that a reciprocal regulation might exist between both neuropeptides, although, to date, no reports have shown that VIP can modulate PACAP expression.

Thus, based on the neuromodulatory activities of NGF, VIP and PACAP, and their effects on the HIV-1 replicative cycle, it is possible to predict that the associated actions of these molecules could influence the pathogenesis of HIV-1 infection in nervous tissue. HIV-1 infects microglial cells and brain-resident macrophages, leading to the local release of neurotoxic HIV-1 proteins, such as gp120, Nef and Tat. Thus, considering the apoptotic potential of HIV-1 gp120 on nervous cells, the ability of VIP and PACAP to induce $\beta$-chemokine production (which inhibits gp120 binding to cell receptors) by astrocytes and microglial cells, along with the neuroprotection offered by NGF, suggests that these molecules can cooperate to counterbalance the harmful effects of HIV-1 gp120 on nervous cells. The abilities of VIP and PACAP to act as endogenous anti-inflammatory agents and of PACAP to transactivate the TrkA receptor, thus mimicking NGF and offering neuronal cell survival, could eventually protect nervous tissue from the local inflammatory responses triggered by the toxic HIV-1 proteins Nef and Tat. 


\section{Limitations and Perspectives}

Considering the systemic aspects of HIV-1 infection, the better understanding of the ability of the NT-neuropeptide network to modulate viral replication in HIV-1 cell reservoirs might bring new challenges for researchers devoted to develop new strategies to control HIV-1 tissue propagation and the infection progress, due to the knowledge pointing to the relevance of these mediators on the physiopathology of HIV-1 infection. The systemic physiological effects resulting from the cross talk between NGF and VIP/PACAP should be considered as potential targets for therapeutic interventions based on the ability of endogenous molecules to restrain HIV-1 replication and propagation in the peripheral tissues and CNS.

Based on the anti-apoptotic activity of NTs via Trk signaling, models intended to rescue neuronal cells from apoptosis induced by HIV-1 proteins have been developed with the aim to provide therapeutic benefits to patients with HIV-1-induced neurocognitive disorders. However, an ideal balance between the neuroprotective effects of NTs and their abilities to promote HIV-1-productive infections should be pursued to provide safe therapies for HIV-1-infected individuals.

The current paradigms of HIV-1-induced cell dysfunction and tissue damage are largely based on the use of ex vivo cell infections, mechanistic insights derived from mouse and nonhuman primate models, and postmortem analyses. The difficulties to access the CNS and to collect samples from living HIV-1-infected individuals and the absence of robust animal models to study HIV1-induced neuropathogenesis represent critical obstacles to significantly improve the knowledge in this field. Nonetheless, we wonder whether, prospectively, an association between the neuroprotective effects of NGF and VIP/PACAP and the anti-inflammatory and anti-HIV-1 activities of both neuropeptides might offer an alternative approach to control HIV-1 infection progression and to prevent the development of cognitive dysfunction secondary to HIV-1 propagation to nervous tissue.

\section{Acknowledgments}

We are grateful to the Hemotherapy Service of the Hospital Clementino Fraga Filho (Federal University of Rio de Janeiro, Brazil) and to the NIH AIDS Research and Reference Reagent Program (Division of AIDS, NIAID, NIH, Bethesda, Md., USA) for continuously supporting our studies. We also acknowledge the grants provided by the Brazilian institutions PAPES/Fiocruz, Conselho Nacional de Desenvolvimento Científico e Tecnológico (CNPq) and Fundação Carlos Chagas Filho de Amparo a Pesquisa do Estado do Rio de Janeiro (Faperf). Artwork by one of the authors (JRT).

\section{References}

1 Dieffenbach CW, Fauci AS: Thirty years of HIV and AIDS: future challenges and opportunities. Ann Intern Med 2011;154:766-771.

$\checkmark 2$ Berger EA, Murphy PM, Farber JM: Chemokine receptors as HIV-1 coreceptors: roles in viral entry, tropism, and disease. Annu Rev Immunol 1999;17:657-700.

3 Paiardini M, Muller-Trutwin M: HIV-associated chronic immune activation. Immunol Rev 2013;254:78-101.

4 Alfano M, Crotti A, Vicenzi E, Poli G: New players in cytokine control of HIV infection. Curr HIV/AIDS Rep 2008;5:27-32.

5 Radziejewski C, Robinson RC: Heterodimers of the neurotrophic factors: formation, isolation, and differential stability. Biochemistry 1993;32:13350-13356.

6 Cowan WM: Viktor Hamburger and Rita Levi-Montalcini: the path to the discovery of nerve growth factor. Annu Rev Neurosci 2001;24:551-600.

7 Fiore M, Chaldakov GN, Aloe L: Nerve growth factor as a signaling molecule for nerve cells and also for the neuroendocrine-immune systems. Rev Neurosci 2009;20:133-145.

8 Scuri M, Samsell L, Piedimonte G: The role of neurotrophins in inflammation and allergy.
Inflamm Allergy Drug Targets 2010;9:173180.

-9 Dickson L, Finlayson K: VPAC and PAC receptors: from ligands to function. Pharmacol Ther 2009;121:294-316.

10 Vaudry D, Falluel-Morel A, Bourgault S, Basille M, Burel D, Wurtz O, Fournier A, Chow BK, Hashimoto H, Galas L, Vaudry $\mathrm{H}$ : Pituitary adenylate cyclase-activating polypeptide and its receptors: 20 years after the discovery. Pharmacol Rev 2009;61:283357.

11 (UNAIDS) JUNPoHA: Global Report: 1 UNAIDS Report on the Global AIDS Epidemic 2012: Global Report. Geneva, World Health Organization (WHO), 2012.

12 Hemelaar J: The origin and diversity of the HIV-1 pandemic. Trends Mol Med 2012;18: 182-192.

13 Nisole S, Saib A: Early steps of retrovirus replicative cycle. Retrovirology 2004;1:9.

14 Karn J, Stoltzfus CM: Transcriptional and posttranscriptional regulation of HIV-1 gene expression. Cold Spring Harb Perspect Med 2012;2:a006916.

15 Lee SK, Potempa M, Swanstrom R: The choreography of HIV-1 proteolytic processing and virion assembly. J Biol Chem 2012;287: 40867-40874.

16 Sundquist WI, Krausslich HG: HIV-1 assembly, budding, and maturation. Cold Spring Harb Perspect Med 2012;2:a006924.

17 Gorry PR, Ancuta P: Coreceptors and HIV-1 pathogenesis. Curr HIV/AIDS Rep 2011;8: 45-53.

18 Ghiglione Y, Turk G: Nef performance in macrophages: the master orchestrator of viral persistence and spread. Curr HIV Res 2011;9: 505-513.

19 Koppensteiner H, Banning C, Schneider C, Hohenberg H, Schindler M: Macrophage internal HIV-1 is protected from neutralizing antibodies. J Virol 2012;86:28262836.

20 Eisele E, Siliciano RF: Redefining the viral reservoirs that prevent HIV-1 eradication. Immunity 2012;37:377-388.

21 Chun TW: Tracking replication-competent HIV reservoirs in infected individuals. Curr Opin HIV AIDS 2013;8:111-116.

22 Massanella M, Martinez-Picado J, Blanco J: Attacking the hiv reservoir from the immune and viral perspective. Curr HIV/AIDS Rep 2013;10:33-41. 
-23 Ho YC, Shan L, Hosmane NN, Wang J, Laskey SB, Rosenbloom DIS, Lai J, Blamkson JN, Siliciano JD, Siliciano RF: Replication-competent noninduced proviruses in the latent reservoir increase barrier to HIV-1 cure. Cell 2013;155:540-551.

-24 An SF, Groves M, Gray F, Scaravilli F: Early entry and widespread cellular involvement of HIV-1 DNA in brains of HIV-1 positive asymptomatic individuals. J Neuropathol Exp Neurol 1999;58:1156-1162.

25 Ganau M, Prisco L, Pescador D, Ganau L: 38 Challenging new targets for CNS-HIV infection. Front Neurol 2012;3:43.

26 Churchill M, Nath A: Where does HIV hide? A focus on the central nervous system. Curr Opin HIV AIDS 2013;8:165-169.

27 Brown A, Zhang H, Lopez P, Pardo CA, Gartner S: In vitro modeling of the HIV-macrophage reservoir. J Leukoc Biol 2006;80:11271135.

28 Igarashi T, Brown CR, Endo Y, BucklerWhite A, Plishka R, Bischofberger N, Hirsch V, Martin MA: Macrophage are the principal reservoir and sustain high virus loads in rhesus macaques after the depletion of CD4+ T cells by a highly pathogenic simian immunodeficiency virus/HIV type 1 chimera (SHIV): implications for HIV-1 infections of humans. Proc Natl Acad Sci USA 2001;98:658-663.

-29 Bingham R, Ahmed N, Rangi P, Johnson M, Tyrer M, Green J: HIV encephalitis despite suppressed viraemia: a case of compartmentalized viral escape. Int J STD AIDS 2011;22: 608-609.

- 30 Ensoli B, Buonaguro L, Barillari G, Fiorelli V, Gendelman R, Morgan RA, Wingfield P, Gallo RC: Release, uptake, and effects of extracellular human immunodeficiency virus type 1 Tat protein on cell growth and viral transactivation. J Virol 1993;67:277-287.

-31 Banks WA, Akerstrom V, Kastin AJ: Adsorptive endocytosis mediates the passage of HIV1 across the blood-brain barrier: evidence for a post-internalization coreceptor. J Cell Sci 1998;111(Pt 4):533-540.

32 Ferrucci A, Nonnemacher MR, Wigdahl B: Human immunodeficiency virus viral protein $\mathrm{R}$ as an extracellular protein in neuropathogenesis. Adv Virus Res 2011;81:165-199.

-33 Churchill MJ, Figueiredo A, Cowley D, Gray L, Purcell DF, Sullivan JS, McPhee DA, Wesselingh SL, Brew BJ, Gorry PR: Transcriptional activity of blood- and cerebrospinal fluidderived nef/long-terminal repeat sequences isolated from a slow progressor infected with nef-deleted human immunodeficiency virus type 1 (HIV-1) who developed HIV-associated dementia. J Neurovirol 2006;12:219-228.

34 Chompre G, Cruz E, Maldonado L, RiveraAmill V, Porter JT, Noel RJ Jr: Astrocytic expression of HIV-1 Nef impairs spatial and recognition memory. Neurobiol Dis 2012; 49C: $128-136$

-35 van Marle G, Henry S, Todoruk T, Sullivan A, Silva C, Rourke SB, Holden J, McArthur JC, Gill MJ, Power C: Human immunodeficiency virus type 1 Nef protein mediates neural cell death: a neurotoxic role for IP-10. Virology 2004;329:302-318.

- 36 Bertrand SJ, Aksenova MV, Mactutus CF, Booze RM: HIV-1 Tat protein variants: critical role for the cysteine region in synaptodendritic injury. Exp Neurol 2013;248:228-235.

37 Shin AH, Thayer SA: Human immunodeficiency virus-1 protein Tat induces excitotoxic loss of presynaptic terminals in hippocampal cultures. Mol Cell Neurosci 2013;54:22-29.

8 Guha D, Nagilla P, Redinger C, Srinivasan A, Schatten GP, Ayyavoo V: Neuronal apoptosis by HIV-1 Vpr: contribution of proinflammatory molecular networks from infected target cells. J Neuroinflammation 2012;9:138.

39 Mukerjee R, Chang JR, Del Valle L, Bagashev A, Gayed MM, Lyde RB, Hawkins BJ, Brailoiu E, Cohen E, Power C, Azizi SA, Gelman BB, Sawaya BE: Deregulation of microRNAs by HIV-1 Vpr protein leads to the development of neurocognitive disorders. J Biol Chem 2011;286:34976-34985.

40 Chen L, Liu J, Xu C, Keblesh J, Zang W, Xiong $\mathrm{H}$ : HIV-1gp120 induces neuronal apoptosis through enhancement of 4-aminopyridinesensitive outward $\mathrm{K}+$ currents. PLoS One 2011;6:e25994.

41 Louboutin JP, Agrawal L, Reyes BA, Van Bockstaele EJ, Strayer DS: HIV-1 gp120-induced injury to the blood-brain barrier: role of metalloproteinases 2 and 9 and relationship to oxidative stress. J Neuropathol Exp Neurol 2010;69:801-816.

-42 Sadagopal S, Lorey SL, Barnett L, Basham R, Lebo L, Erdem H, Haman K, Avison M, Waddell K, Haas DW, Kalams SA: Enhancement of human immunodeficiency virus (HIV)specific CD8+ T cells in cerebrospinal fluid compared to those in blood among antiretroviral therapy-naive HIV-positive subjects. J Virol 2008;82:10418-10428.

43 Pan W, Stone KP, Hsuchou H, Manda VK, Zhang Y, Kastin AJ: Cytokine signaling modulates blood-brain barrier function. Curr Pharm Des 2011;17:3729-3740.

44 Catalfamo M, Le Saout C, Lane HC: The role of cytokines in the pathogenesis and treatment of HIV infection. Cytokine Growth Factor Rev 2012;23:207-214.

45 Williams DW, Eugenin EA, Calderon TM, Berman JW: Monocyte maturation, HIV susceptibility, and transmigration across the blood brain barrier are critical in HIV neuropathogenesis. J Leukoc Biol 2012;91:401-415.

-46 Koedel U, Kohleisen B, Sporer B, Lahrtz F, Ovod V, Fontana A, Erfle V, Pfister HW: HIV type 1 Nef protein is a viral factor for leukocyte recruitment into the central nervous system. J Immunol 1999;163:1237-1245.

47 Eisfeld C, Reichelt D, Evers S, Husstedt I: CSF penetration by antiretroviral drugs. CNS Drugs 2013;27:31-55.

48 Letendre S: Central nervous system complications in HIV disease: HIV-associated neurocognitive disorder. Top Antivir Med 2011;19: 137-142.
49 Spudich S, Gonzalez-Scarano F: HIV-1-related central nervous system disease: current issues in pathogenesis, diagnosis, and treatment. Cold Spring Harb Perspect Med 2012; 2:a007120.

50 Weber E, Blackstone K, Woods SP: Cognitive neurorehabilitation of HIV-associated neurocognitive disorders: a qualitative review and call to action. Neuropsychol Rev 2013;23:81-98.

51 Klatt NR, Funderburg NT, Brenchley JM: Microbial translocation, immune activation, and HIV disease. Trends Microbiol 2013;21:6-13.

52 Taiwo B, Barcena L, Tressler R: Understanding and controlling chronic immune activation in the HIV-infected patients suppressed on combination antiretroviral therapy. Curr HIV/AIDS Rep 2013;10:21-32.

53 Vyakarnam A, McKeating J, Meager A, Beverley PC: Tumour necrosis factors (alpha, beta) induced by HIV-1 in peripheral blood mononuclear cells potentiate virus replication. AIDS 1990;4:21-27.

54 Poli G, Kinter AL, Fauci AS: Interleukin 1 induces expression of the human immunodeficiency virus alone and in synergy with interleukin 6 in chronically infected U1 cells: inhibition of inductive effects by the interleukin 1 receptor antagonist. Proc Natl Acad Sci USA 1994;91:108-112.

55 Saville MW, Taga K, Foli A, Broder S, Tosato $G$, Yarchoan R: Interleukin-10 suppresses human immunodeficiency virus-1 replication in vitro in cells of the monocyte/ macrophage lineage. Blood 1994;83:35913599.

56 Vitkovic L, Wood GP, Major EO, Fauci AS: Human astrocytes stimulate HIV-1 expression in a chronically infected promonocyte clone via interleukin-6. AIDS Res Hum Retroviruses 1991;7:723-727.

57 Souza TM, Rodrigues DQ, Passaes CP, Barreto-de-Souza V, Aguiar RS, Temerozo JR, Morgado MG, Fontes CF, Araujo EG, Bou-Habib DC: The nerve growth factor reduces APOBEC3G synthesis and enhances HIV-1 transcription and replication in human primary macrophages. Blood 2011;117:2944-2952.

58 Regis EG, Barreto-de-Souza V, Morgado MG, Bozza MT, Leng L, Bucala R, Bou-Habib DC: Elevated levels of macrophage migration inhibitory factor (MIF) in the plasma of HIV1-infected patients and in HIV-1-infected cell cultures: a relevant role on viral replication. Virology 2010;399:31-38.

59 Imamichi T, Yang J, Huang DW, Brann TW, Fullmer BA, Adelsberger JW, Lempicki RA, Baseler MW, Lane HC: IL-27, a novel antiHIV cytokine, activates multiple interferoninducible genes in macrophages. AIDS 2008; 22:39-45

60 Verani A, Scarlatti G, Comar M, Tresoldi E, Polo S, Giacca M, Lusso P, Siccardi AG, Vercelli D: C-C chemokines released by lipopolysaccharide (LPS)-stimulated human macrophages suppress HIV-1 infection in both macrophages and T cells. J Exp Med 1997;185: 805-816. 
61 Temerozo JR, Joaquim R, Regis EG, Savino W, Bou-Habib DC: Macrophage resistance to HIV-1 infection is enhanced by the neuropeptides VIP and PACAP. PLoS One 2013; 8:e67701.

62 Malim MH, Bieniasz PD: HIV restriction factors and mechanisms of evasion. Cold Spring Harb Perspect Med 2012;2:a006940.

63 Romani B, Engelbrecht S, Glashoff RH: Antiviral roles of APOBEC proteins against HIV-1 and suppression by Vif. Arch Virol 2009;154: 1579-1588.

64 Holmes RK, Koning FA, Bishop KN, Malim MH: APOBEC3F can inhibit the accumulation of HIV-1 reverse transcription products in the absence of hypermutation. Comparisons with APOBEC3G. J Biol Chem 2007;282:25872595.

65 Newman EN, Holmes RK, Craig HM, Klein KC, Lingappa JR, Malim MH, Sheehy AM: Antiviral function of APOBEC3G can be dissociated from cytidine deaminase activity. Curr Biol 2005; 15:166-170.

-66 Venkatesh S, Bieniasz PD: Mechanism of HIV-1 virion entrapment by tetherin. PLoS Pathog 2013;9:e1003483.

-67 Serra-Moreno R, Zimmermann K, Stern LJ, Evans DT: Tetherin/BST-2 antagonism by Nef depends on a direct physical interaction between Nef and tetherin, and on clathrinmediated endocytosis. PLoS Pathog 2013; 9:e1003487.

-68 McNatt MW, Zang T, Bieniasz PD: Vpu binds directly to tetherin and displaces it from nascent virions. PLoS Pathog 2013;9:e1003299.

69 Chutiwitoonchai N, Hiyoshi M, Hiyoshi-Yoshidomi Y, Hashimoto M, Tokunaga K, Suzu $S$ : Characteristics of IFITM, the newly identified IFN-inducible anti-HIV-1 family proteins. Microbes Infect 2013;15:280-290.

70 Lu J, Pan Q, Rong L, He W, Liu SL, Liang C: The IFITM proteins inhibit HIV-1 infection. J Virol 2011;85:2126-2137.

71 Laguette N, Sobhian B, Casartelli N, Ringeard M, Chable-Bessia C, Segeral E, Yatim A, Emiliani S, Schwartz O, Benkirane M: SAMHD1 is the dendritic- and myeloid-cell-specific HIV1 restriction factor counteracted by Vpx. Nature 2011;474:654-657.

72 Amie SM, Bambara RA, Kim B: GTP is the primary activator of the anti-HIV restriction factor SAMHD1. J Biol Chem 2013;288: 25001-25006

-73 Beloglazova N, Flick R, Tchigvintsev A, Brown G, Popovic A, Nocek B, Yakunin AF: Nuclease activity of the human SAMHD1 protein implicated in the Aicardi-Goutieres syndrome and HIV-1 restriction. J Biol Chem 2013;288:8101-8110.

74 Boudinot P, Riffault S, Salhi S, Carrat C, Sedlik C, Mahmoudi N, Charley B, Benmansour A: Vesicular stomatitis virus and pseudorabies virus induce a vig1/cig5 homologue in mouse dendritic cells via different pathways. J Gen Virol 2000;81:2675-2682.

75 Hinson ER, Joshi NS, Chen JH, Rahner C, Jung YW, Wang X, Kaech SM, Cresswell P:
Viperin is highly induced in neutrophils and macrophages during acute and chronic lymphocytic choriomeningitis virus infection. J Immunol 2010;184:5723-5731.

-76 Harper MS, Barrett BS, Smith DS, Li SX, Gibbert K, Dittmer U, Hasenkrug KJ, Santiago ML: IFN-alpha treatment inhibits acute Friend retrovirus replication primarily through the antiviral effector molecule Apobec3. J Immunol 2013;190:1583-1590.

77 Helbig KJ, Carr JM, Calvert JK, Wati S, Clarke JN, Eyre NS, Narayana SK, Fiches GN, McCartney EM, Beard MR: Viperin is induced following dengue virus type-2 (DENV-2) infection and has anti-viral actions requiring the C-terminal end of viperin. PLoS Negl Trop Dis 2013;7:e2178.

78 Wang S, Wu X, Pan T, Song W, Wang Y, Zhang F, Yuan Z: Viperin inhibits hepatitis $\mathrm{C}$ virus replication by interfering with binding of NS5A to host protein hVAP-33. J Gen Virol 2012;93:83-92.

79 Wang X, Hinson ER, Cresswell P: The interferon-inducible protein viperin inhibits influenza virus release by perturbing lipid rafts. Cell Host Microbe 2007;2:96-105.

80 Szretter KJ, Brien JD, Thackray LB, Virgin HW Cresswell P, Diamond MS: The interferon-inducible gene viperin restricts West Nile virus pathogenesis. J Virol 2011;85:11557-11566.

81 Nasr N, Maddocks S, Turville SG, Harman AN, Woolger N, Helbig KJ, Wilkinson J, Bye CR, Wright TK, Rambukwelle D, Donaghy H, Beard MR, Cunningham AL: HIV-1 infection of human macrophages directly induces viperin which inhibits viral production. Blood 2012;120:778-788.

$>82$ Tan KS, Ng WC, Seet JE, Olfat F, Engelward BP, Chow VT: Investigating the efficacy of pamidronate, a chemical inhibitor of farnesyl pyrophosphate synthase, in the inhibition of influenza virus infection in vitro and in vivo. Mol Med Rep 2014;9:51-56.

83 Goujon C, Moncorge O, Bauby H, Doyle T, Ward CC, Schaller T, Hue S, Barclay WS, Schulz R, Malim MH: Human MX2 is an interferon-induced post-entry inhibitor of HIV-1 infection. Nature 2013;502:559-562.

84 Skaper SD: The biology of neurotrophins, signalling pathways, and functional peptide mimetics of neurotrophins and their receptors. CNS Neurol Disord Drug Targets 2008;7:4662.

85 Skaper SD: The neurotrophin family of neurotrophic factors: an overview. Methods $\mathrm{Mol}$ Biol 2012;846:1-12.

-86 Alsina FC, Irala D, Fontanet PA, Hita FJ, Ledda F, Paratcha G: Sprouty4 is an endogenous negative modulator of TrkA signaling and neuronal differentiation induced by NGF. PLoS One 2012;7:e32087.

87 Blochl A, Blochl R: A cell-biological model of p75NTR signaling. J Neurochem 2007;102: 289-305.

88 Dechant G: Molecular interactions between neurotrophin receptors. Cell Tissue Res 2001; 305:229-238.
89 Zhang C, Helmsing S, Zagrebelsky M, Schirrmann T, Marschall AL, Schungel M, Korte M, Hust M, Dubel S: Suppression of p75 neurotrophin receptor surface expression with intrabodies influences $\mathrm{Bcl}-\mathrm{xL}$ mRNA expression and neurite outgrowth in PC12 cells. PLoS One 2012;7:e30684.

90 Ibanez CF, Simi A: p75 neurotrophin receptor signaling in nervous system injury and degeneration: paradox and opportunity. Trends Neurosci 2012;35:431-440.

91 Luther JA, Birren SJ: Neurotrophins and target interactions in the development and regulation of sympathetic neuron electrical and synaptic properties. Auton Neurosci 2009; 151:46-60.

$\$ 2$ Park H, Poo MM: Neurotrophin regulation of neural circuit development and function. Nat Rev Neurosci 2013;14:7-23.

$\$ 93$ Peters EM, Raap U, Welker P, Tanaka A, Matsuda H, Pavlovic-Masnicosa S, Hendrix S, Pincelli C: Neurotrophins act as neuroendocrine regulators of skin homeostasis in health and disease. Horm Metab Res 2007;39:110-124.

\$4 Fargali S, Sadahiro M, Jiang C, Frick AL, Indall T, Cogliani V, Welagen J, Lin WJ, Salton SR: Role of neurotrophins in the development and function of neural circuits that regulate energy homeostasis. J Mol Neurosci 2012;48:654-659.

$\checkmark 95$ Freund-Michel V, Frossard N: The nerve growth factor and its receptors in airway inflammatory diseases. Pharmacol Ther 2008; 117:52-76.

96 Joachim RA, Noga O, Sagach V, Hanf G, Fliege H, Kocalevent RD, Peters EM, Klapp BF: Correlation between immune and neuronal parameters and stress perception in allergic asthmatics. Clin Exp Allergy 2008;38:283-290.

-97 Marshall JS, Gomi K, Blennerhassett MG, Bienenstock J: Nerve growth factor modifies the expression of inflammatory cytokines by mast cells via a prostanoid-dependent mechanism. J Immunol 1999;162:4271-4276.

98 Otten U, Ehrhard P, Peck R: Nerve growth factor induces growth and differentiation of human B lymphocytes. Proc Natl Acad Sci USA 1989;86:10059-10063.

99 Kimata H, Yoshida A, Ishioka C, Kusunoki T, Hosoi S, Mikawa H: Nerve growth factor specifically induces human IgG4 production. Eur J Immunol 1991;21:137-141.

100 Tsuda T, Wong D, Dolovich J, Bienenstock J, Marshall J, Denburg JA: Synergistic effects of nerve growth factor and granulocytemacrophage colony-stimulating factor on human basophilic cell differentiation. Blood 1991;77:971-979.

101 Turrini P, Zaccaria ML, Aloe L: Presence and possible functional role of nerve growth factor in the thymus. Cell Mol Biol (Noisyle-grand) 2001;47:55-64.

102 Barouch R, Appel E, Kazimirsky G, Braun A, Renz H, Brodie C: Differential regulation of neurotrophin expression by mitogens and neurotransmitters in mouse lymphocytes. J Neuroimmunol 2000;103:112-121. 
-103 Santambrogio L, Benedetti M, Chao MV, Muzaffar R, Kulig K, Gabellini N, Hochwald G: Nerve growth factor production by lymphocytes. J Immunol 1994;153:4488-4495.

104 Boyle MD, Lawman MJ, Gee AP, Young M: Nerve growth factor: a chemotactic factor for polymorphonuclear leukocytes in vivo. J Immunol 1985;134:564-568.

105 Gee AP, Boyle MD, Munger KL, Lawman MJ, Young M: Nerve growth factor: stimulation of polymorphonuclear leukocyte chemotaxis in vitro. Proc Natl Acad Sci USA 1983;80:7215-7218.

-106 Kannan Y, Usami K, Okada M, Shimizu S, Matsuda $\mathrm{H}$ : Nerve growth factor suppresses apoptosis of murine neutrophils. Biochem Biophys Res Commun 1992;186:1050-1056.

-107 Kannan Y, Matsuda H, Ushio H, Kawamoto $\mathrm{K}$, Shimada Y: Murine granulocyte-macrophage and mast cell colony formation promoted by nerve growth factor. Int Arch Allergy Immunol 1993;102:362-367.

108 Piedimonte G: Contribution of neuroimmune mechanisms to airway inflammation and remodeling during and after respiratory syncytial virus infection. Pediatr Infect Dis J 2003;22:S66-S74; discussion S74-S75.

109 Othumpangat S, Gibson LF, Samsell L, Piedimonte G: NGF is an essential survival factor for bronchial epithelial cells during respiratory syncytial virus infection. PLoS One 2009;4:e6444.

110 Valderrama X, Rapin N, Misra V: Zhangfei, a novel regulator of the human nerve growth factor receptor, trkA. J Neurovirol 2008; 14 : 425-436.

-111 Camarena V, Kobayashi M, Kim JY, Roehm P, Perez R, Gardner J, Wilson AC, Mohr I, Chao MV: Nature and duration of growth factor signaling through receptor tyrosine kinases regulates HSV-1 latency in neurons. Cell Host Microbe 2010;8:320-330.

112 Chuenkova MV, PereiraPerrin M: Chagas' disease parasite promotes neuron survival and differentiation through TrkA nerve growth factor receptor. J Neurochem 2004; 91:385-394.

-113 Aridgides D, Salvador R, PereiraPerrin M: Trypanosoma cruzi coaxes cardiac fibroblasts into preventing cardiomyocyte death by activating nerve growth factor receptor TrkA. PLoS One 2013;8:e57450.

114 Ensoli F, Ensoli B, Thiele CJ: HIV-1 gene expression and replication in neuronal and glial cell lines with immature phenotype: effects of nerve growth factor. Virology 1994; 200:668-676.

$\checkmark 115$ Recio JA, Aranda A: Activation of the HIV-1 long terminal repeat by nerve growth factor. J Biol Chem 1997;272:26807-26810.

- 116 Garaci E, Caroleo MC, Aloe L, Aquaro S, Piacentini M, Costa N, Amendola A, Micera A, Calio R, Perno CF, Levi-Montalcini R: Nerve growth factor is an autocrine factor essential for the survival of macrophages infected with HIV. Proc Natl Acad Sci USA 1999;96: 14013-14018.
117 Samah B, Porcheray F, Gras G: Neurotrophins modulate monocyte chemotaxis without affecting macrophage function. Clin Exp Immunol 2008;151:476-486.

118 Samah B, Porcheray F, Dereuddre-Bosquet N, Gras G: Nerve growth factor stimulation promotes CXCL-12 attraction of monocytes but decreases human immunodeficiency virus replication in attracted population. J Neurovirol 2009;15:71-80.

119 Webber CA, Salame J, Luu GL, Acharjee S, Ruangkittisakul A, Martinez JA, Jalali H, Watts R, Ballanyi K, Guo GF, Zochodne DW, Power C: Nerve growth factor acts through the TrkA receptor to protect sensory neurons from the damaging effects of the HIV-1 viral protein, Vpr. Neuroscience 2013;252:512-525.

120 Avdoshina V, Bachis A, Mocchetti I: Synaptic dysfunction in human immunodeficiency virus type-1-positive subjects: inflammation or impaired neuronal plasticity? J Intern Med 2013;273:454-465.

121 Bachis A, Avdoshina V, Zecca L, Parsadanian M, Mocchetti I: Human immunodeficiency virus type 1 alters brain-derived neurotrophic factor processing in neurons. J Neurosci 2012;32:9477-9484.

122 Nosheny RL, Ahmed F, Yakovlev A, Meyer EM, Ren K, Tessarollo L, Mocchetti I: Brain-derived neurotrophic factor prevents the nigrostriatal degeneration induced by human immunodeficiency virus-1 glycoprotein 120 in vivo. Eur J Neurosci 2007;25: 2275-2284.

123 Schifitto G, Yiannoutsos C, Simpson DM, Adornato BT, Singer EJ, Hollander H, Marra CM, Rubin M, Cohen BA, Tucker T, Koralnik IJ, Katzenstein D, Haidich B, Smith ME, Shriver S, Millar L, Clifford DB, McArthur JC: Long-term treatment with recombinant nerve growth factor for HIV-associated sensory neuropathy. Neurology 2001;57:13131316.

124 McArthur JC, Yiannoutsos C, Simpson DM, Adornato BT, Singer EJ, Hollander H, Marra C, Rubin M, Cohen BA, Tucker T, Navia BA, Schifitto G, Katzenstein D, Rask C, Zaborski L, Smith ME, Shriver S, Millar L, Clifford DB, Karalnik IJ: A phase II trial of nerve growth factor for sensory neuropathy associated with HIV infection. AIDS Clinical Trials Group Team 291. Neurology 2000;54: 1080-1088.

125 Garaci E, Aquaro S, Lapenta C, Amendola A, Spada M, Covaceuszach S, Perno CF, Belardelli F: Anti-nerve growth factor Ab abrogates macrophage-mediated HIV-1 infection and depletion of CD4+ T lymphocytes in hu-SCID mice. Proc Natl Acad Sci USA 2003;100:8927-8932.

126 Said SI, Mutt V: Polypeptide with broad biological activity: isolation from small intestine. Science 1970;169:1217-1218.

127 Smalley SG, Barrow PA, Foster N: Immunomodulation of innate immune responses by vasoactive intestinal peptide (VIP): its thera- peutic potential in inflammatory disease. Clin Exp Immunol 2009;157:225-234.

128 Delgado M, Ganea D: Vasoactive intestinal peptide: a neuropeptide with pleiotropic immune functions. Amino Acids 2013;45:2539.

129 Miyata A, Arimura A, Dahl RR, Minamino N, Uehara A, Jiang L, Culler MD, Coy DH: Isolation of a novel 38 residue-hypothalamic polypeptide which stimulates adenylate cyclase in pituitary cells. Biochem Biophys Res Commun 1989;164:567-574.

130 Miyata A, Jiang L, Dahl RD, Kitada C, Kubo K, Fujino M, Minamino N, Arimura A: Isolation of a neuropeptide corresponding to the N-terminal 27 residues of the pituitary adenylate cyclase activating polypeptide with 38 residues (PACAP38). Biochem Biophys Res Commun 1990;170:643-648.

131 Hoyle CH: Neuropeptide families: evolutionary perspectives. Regul Pept 1998;73:1-33.

132 Gaytan F, Martinez-Fuentes AJ, Garcia-Navarro F, Vaudry H, Aguilar E: Pituitary adenylate cyclase-activating peptide (PACAP) immunolocalization in lymphoid tissues of the rat. Cell Tissue Res 1994;276:223-227.

133 Koves K, Arimura A, Gorcs TG, Somogyvari-Vigh A: Comparative distribution of immunoreactive pituitary adenylate cyclase activating polypeptide and vasoactive intestinal polypeptide in rat forebrain. Neuroendocrinology 1991;54:159-169.

134 Arimura A, Somogyvari-Vigh A, Miyata A, Mizuno K, Coy DH, Kitada C: Tissue distribution of PACAP as determined by RIA: highly abundant in the rat brain and testes. Endocrinology 1991;129:2787-2789.

135 Uddman R, Luts A, Absood A, Arimura A, Ekelund M, Desai H, Hakanson R, Hambreaus G, Sundler F: PACAP, a VIP-like peptide, in neurons of the esophagus. Regul Pept 1991;36:415-422.

136 Vigh S, Arimura A, Koves K, SomogyvariVigh A, Sitton J, Fermin CD: Immunohistochemical localization of the neuropeptide, pituitary adenylate cyclase activating polypeptide (PACAP), in human and primate hypothalamus. Peptides 1991;12:313-318.

137 Souza-Moreira L, Campos-Salinas J, Caro M, Gonzalez-Rey E: Neuropeptides as pleiotropic modulators of the immune response. Neuroendocrinology 2011;94:89-100.

138 Pisegna JR, Wank SA: Molecular cloning and functional expression of the pituitary adenylate cyclase-activating polypeptide type I receptor. Proc Natl Acad Sci USA 1993;90:6345-6349.

139 Lutz EM, Sheward WJ, West KM, Morrow JA, Fink G, Harmar AJ: The VIP2 receptor: molecular characterisation of a cDNA encoding a novel receptor for vasoactive intestinal peptide. FEBS Lett 1993;334:3-8.

140 Sreedharan SP, Patel DR, Huang JX, Goetzl EJ: Cloning and functional expression of a human neuroendocrine vasoactive intestinal peptide receptor. Biochem Biophys Res Commun 1993;193:546-553. 
141 Dickson L, Aramori I, McCulloch J, Sharkey J, Finlayson K: A systematic comparison of intracellular cyclic AMP and calcium signalling highlights complexities in human VPAC/PAC receptor pharmacology. Neuropharmacology 2006;51:1086-1098.

-142 Ogi K, Miyamoto Y, Masuda Y, Habata Y, Hosoya M, Ohtaki T, Masuo Y, Onda H, Fujino M: Molecular cloning and functional expression of a cDNA encoding a human pituitary adenylate cyclase activating polypeptide receptor. Biochem Biophys Res Commun 1993;196:1511-1521.

-143 Svoboda M, Tastenoy M, Van Rampelbergh J, Goossens JF, De Neef P, Waelbroeck M, Robberecht P: Molecular cloning and functional characterization of a human VIP receptor from SUP-T1 lymphoblasts. Biochem Biophys Res Commun 1994;205: 1617-1624.

144 Morrow JA, Lutz EM, West KM, Fink G, Harmar AJ: Molecular cloning and expression of a cDNA encoding a receptor for pituitary adenylate cyclase activating polypeptide (PACAP). FEBS Lett 1993;329:99105.

145 Bokaei PB, Ma XZ, Byczynski B, Keller J, Sakac D, Fahim S, Branch DR: Identification and characterization of five-transmembrane isoforms of human vasoactive intestinal peptide and pituitary adenylate cyclase-activating polypeptide receptors. Genomics 2006;88:791-800.

146 Blechman J, Levkowitz G: Alternative splicing of the pituitary adenylate cyclase-activating polypeptide receptor PAC1: mechanisms of fine tuning of brain activity. Front Endocrinol (Lausanne) 2013;4:55.

-147 Delgado M, Martinez C, Johnson MC, Gomariz RP, Ganea D: Differential expression of vasoactive intestinal peptide receptors 1 and 2 (VIP-R1 and VIP-R2) mRNA in murine lymphocytes. J Neuroimmunol 1996;68:2738.

148 Johnson MC, McCormack RJ, Delgado M, Martinez C, Ganea D: Murine T-lymphocytes express vasoactive intestinal peptide receptor 1 (VIP-R1) mRNA. J Neuroimmunol 1996;68:109-119.

149 Delgado M, Pozo D, Martinez C, Garrido E, Leceta J, Calvo JR, Gomariz RP: Characterization of gene expression of VIP and VIP1receptor in rat peritoneal lymphocytes and macrophages. Regul Pept 1996;62:161-166.

150 Pozo D, Delgado M, Martinez C, Gomariz RP, Guerrero JM, Calvo JR: Functional characterization and mRNA expression of pituitary adenylate cyclase activating polypeptide (PACAP) type I receptors in rat peritoneal macrophages. Biochim Biophys Acta 1997;1359:250-262.

151 Delgado M, Reduta A, Sharma V, Ganea D: VIP/PACAP oppositely affects immature and mature dendritic cell expression of CD80/CD86 and the stimulatory activity for CD4(+) T cells. J Leukoc Biol 2004;75:11221130.
152 Fabricius D, O’Dorisio MS, Blackwell S, Jahrsdorfer B: Human plasmacytoid dendritic cell function: inhibition of IFN-alpha secretion and modulation of immune phenotype by vasoactive intestinal peptide. J Immunol 2006;177:5920-5927.

153 Tan YV, Waschek JA: Targeting VIP and PACAP receptor signalling: new therapeutic strategies in multiple sclerosis. ASN Neuro 2011;3:e00065.

154 Ghatei MA, Takahashi K, Suzuki Y, Gardiner J, Jones PM, Bloom SR: Distribution, molecular characterization of pituitary adenylate cyclase-activating polypeptide and its precursor encoding messenger RNA in human and rat tissues. J Endocrinol 1993;136: 159-166.

155 Werkstrom V, Alm P, Persson K, Andersson KE: Inhibitory innervation of the guinea-pig urethra; roles of CO, NO and VIP. J Auton Nerv Syst 1998;74:33-42.

-156 Leceta J, Martinez MC, Delgado M, Garrido E, Gomariz RP: Lymphoid cell subpopulations containing vasoactive intestinal peptide in the rat. Peptides 1994;15:791-797.

157 Abad C, Martinez C, Leceta J, Juarranz MG, Delgado M, Gomariz RP: Pituitary adenylate-cyclase-activating polypeptide expression in the immune system. Neuroimmunomodulation 2002;10:177-186.

158 Brenneman DE: Neuroprotection: a comparative view of vasoactive intestinal peptide and pituitary adenylate cyclase-activating polypeptide. Peptides 2007;28:1720-1726.

159 Sanchez A, Tripathy D, Grammas P: RANTES release contributes to the protective action of PACAP38 against sodium nitroprusside in cortical neurons. Neuropeptides 2009;43:315-320.

160 Brenneman DE, Hauser J, Spong CY, Phillips TM, Pert CB, Ruff M: VIP and D-alapeptide $\mathrm{T}$-amide release chemokines which prevent HIV-1 gp120-induced neuronal death. Brain Res 1999;838:27-36.

161 Brenneman DE, Hauser JM, Spong C, Phillips TM: Chemokine release is associated with the protective action of PACAP-38 against HIV envelope protein neurotoxicity. Neuropeptides 2002;36:271-280.

162 Abad C, Waschek JA: Immunomodulatory roles of VIP and PACAP in models of multiple sclerosis. Curr Pharm Des 2011;17: 1025-1035.

163 Delgado M, Chorny A, Ganea D, GonzalezRey E: Vasoactive intestinal polypeptide induces regulatory dendritic cells that prevent acute graft versus host disease and leukemia relapse after bone marrow transplantation. Ann NY Acad Sci 2006;1070:226-232.

164 Gonzalez-Rey E, Delgado-Maroto V, Souza Moreira L, Delgado M: Neuropeptides as therapeutic approach to autoimmune diseases. Curr Pharm Des 2010;16:3158-3172.

165 Gomariz RP, Gutierrez-Canas I, Arranz A, Carrion M, Juarranz Y, Leceta J, Martinez C: Peptides targeting Toll-like receptor signalling pathways for novel immune thera- peutics. Curr Pharm Des 2010;16:10631080.

166 Jiang X, McClellan SA, Barrett RP, Zhang Y, Hazlett LD: Vasoactive intestinal peptide downregulates proinflammatory TLRs while upregulating anti-inflammatory TLRs in the infected cornea. J Immunol 2012;189:269278.

167 Arranz A, Abad C, Juarranz Y, Torroba M, Rosignoli F, Leceta J, Gomariz RP, Martinez C: Effect of VIP on TLR2 and TLR4 expression in lymph node immune cells during TNBS-induced colitis. Ann NY Acad Sci 2006;1070:129-134.

168 Gutierrez-Canas I, Juarranz Y, Santiago B, Arranz A, Martinez C, Galindo M, Paya M, Gomariz RP, Pablos JL: VIP down-regulates TLR4 expression and TLR4-mediated chemokine production in human rheumatoid synovial fibroblasts. Rheumatology (Oxford) $2006 ; 45: 527-532$.

169 Foster N, Lea SR, Preshaw PM, Taylor JJ: Pivotal advance: vasoactive intestinal peptide inhibits up-regulation of human monocyte TLR 2 and TLR 4 by LPS and differentiation of monocytes to macrophages. J Leukoc Biol 2007;81:893-903.

170 Mao SS, Hua R, Zhao XP, Qin X, Sun ZQ, Zhang Y, Wu YQ, Jia MX, Cao JL, Zhang YM: Exogenous administration of PACAP alleviates traumatic brain injury in rats through a mechanism involving the TLR4/ MyD88/NF- $\kappa B$ pathway. J Neurotrauma 2012;29:1941-1959.

171 Khan AM, Li M, Abdulnour-Nakhoul S, Maderdrut JL, Simon EE, Batuman V: Delayed administration of pituitary adenylate cyclase-activating polypeptide 38 ameliorates renal ischemia/reperfusion injury in mice by modulating Toll-like receptors. Peptides 2012;38:395-403.

172 Li M, Khan AM, Maderdrut JL, Simon EE, Batuman V: The effect of PACAP38 on MyD88-mediated signal transduction in ischemia-/hypoxia-induced acute kidney injury. Am J Nephrol 2010;32:522-532.

173 Sacerdote P, Ruff MR, Pert CB: Vasoactive intestinal peptide 1-12: a ligand for the CD4 (T4)/human immunodeficiency virus receptor. J Neurosci Res 1987;18:102-107.

174 Ruff MR, Martin BM, Ginns EI, Farrar WL, Pert CB: CD4 receptor binding peptides that block HIV infectivity cause human monocyte chemotaxis. Relationship to vasoactive intestinal polypeptide. FEBS Lett 1987;211: $17-22$.

175 Brenneman DE, Westbrook GL, Fitzgerald SP, Ennist DL, Elkins KL, Ruff MR, Pert CB: Neuronal cell killing by the envelope protein of HIV and its prevention by vasoactive intestinal peptide. Nature 1988;335:639642.

176 Pert CB, Smith CC, Ruff MR, Hill JM: AIDS and its dementia as a neuropeptide disorder: role of VIP receptor blockade by human immunodeficiency virus envelope. Ann Neurol 1988;23(suppl):S71-S73. 
177 Nguyen TD: Peptide T from human immunodeficiency virus envelope does not interact with hepatic, intestinal and colonic vasoactive intestinal peptide (VIP) receptors. Peptides 1988;9:425-428.

-178 Bokaei PB, Ma XZ, Sakac D, Branch DR: HIV-1 integration is inhibited by stimulation of the VPAC2 neuroendocrine receptor. Virology 2007;362:38-49.

-179 Branch DR, Valenta LJ, Yousefi S, Sakac D, Singla R, Bali M, Sahai BM, Ma XZ: VPAC1 is a cellular neuroendocrine receptor expressed on $\mathrm{T}$ cells that actively facilitates productive HIV-1 infection. AIDS 2002;16: 309-319.

$>180 \mathrm{Du}$ K, Couvineau A, Rouyer-Fessard C, Nicole P, Laburthe M: Human VPAC1 receptor selectivity filter. Identification of a critical domain for restricting secretin binding. J Biol Chem 2002;277:37016-37022.

181 Nicole P, Lins L, Rouyer-Fessard C, Drouot C, Fulcrand P, Thomas A, Couvineau A, Martinez J, Brasseur R, Laburthe M: Identification of key residues for interaction of vasoactive intestinal peptide with human VPAC1 and VPAC2 receptors and development of a highly selective VPAC1 receptor agonist. Alanine scanning and molecular modeling of the peptide. J Biol Chem 2000; 275:24003-24012.

182 Moro O, Lerner EA: Maxadilan, the vasodilator from sand flies, is a specific pituitary adenylate cyclase activating peptide type I receptor agonist. J Biol Chem 1997;272:966970.

183 Peruzzi M, Azzari C, Rossi ME, De Martino $M$, Vierucci A: Inhibition of natural killer cell cytotoxicity and interferon gamma production by the envelope protein of HIV and prevention by vasoactive intestinal peptide. AIDS Res Hum Retroviruses 2000;16:10671073.

184 Pincus DW, DiCicco-Bloom E, Black IB: Trophic mechanisms regulate mitotic neuronal precursors: role of vasoactive intestinal peptide (VIP). Brain Res 1994;663:5160.

185 Yuhara A, Ishii K, Nishio C, Abiru Y, Yamada $M$, Nawa $H$, Hatanaka $H$, Takei $N$ : PACAP and NGF cooperatively enhance choline acetyltransferase activity in postnatal basal forebrain neurons by complementary induction of its different mRNA species. Biochem Biophys Res Commun 2003;301: 344-349.
186 Sakai Y, Hashimoto H, Shintani N, Katoh H, Negishi M, Kawaguchi C, Kasai A, Baba A: PACAP activates Racl and synergizes with NGF to activate ERK1/2, thereby inducing neurite outgrowth in PC12 cells. Brain Res Mol Brain Res 2004;123:18-26.

187 Grumolato L, Louiset E, Alexandre D, AitAli D, Turquier V, Fournier A, Fasolo A, Vaudry H, Anouar Y: PACAP and NGF regulate common and distinct traits of the sympathoadrenal lineage: effects on electrical properties, gene markers and transcription factors in differentiating PC12 cells. Eur J Neurosci 2003; 17:71-82.

188 Jamen F, Bouschet T, Laden JC, Bockaert J, Brabet P: Up-regulation of the PACAP type1 receptor (PAC1) promoter by neurotrophins in rat PC12 cells and mouse cerebellar granule cells via the Ras/mitogen-activated protein kinase cascade. J Neurochem 2002; 82:1199-1207.

189 Sakai Y, Hashimoto H, Shintani N, Tomimoto S, Tanaka K, Ichibori A, Hirose M, Baba A: Involvement of p38 MAP kinase pathway in the synergistic activation of PACAP mRNA expression by NGF and PACAP in PC12h cells. Biochem Biophys Res Commun 2001;285:656-661.

190 Pereira PA, Cardoso A, Paula-Barbosa MM: Nerve growth factor restores the expression of vasopressin and vasoactive intestinal polypeptide in the suprachiasmatic nucleus of aged rats. Brain Res 2005;1048:123-130.

191 Paula-Barbosa MM, Silva SM, Andrade JP, Cadete-Leite A, Madeira MD: Nerve growth factor restores mRNA levels and the expression of neuropeptides in the suprachiasmatic nucleus of rats submitted to chronic ethanol treatment and withdrawal. J Neurocytol 2001;30:195-207.

192 Korkmaz OT, Tuncel N, Tuncel M, Oncu EM, Sahinturk V, Celik M: Vasoactive intestinal peptide (VIP) treatment of parkinsonian rats increases thalamic gamma-aminobutyric acid (GABA) levels and alters the release of nerve growth factor (NGF) by mast cells. J Mol Neurosci 2010;41:278-287.

193 Dallos A, Kiss M, Polyanka H, Dobozy A, Kemeny L, Husz S: Effects of the neuropeptides substance $\mathrm{P}$, calcitonin gene-related peptide, vasoactive intestinal polypeptide and galanin on the production of nerve growth factor and inflammatory cytokines in cultured human keratinocytes. Neuropeptides 2006;40:251-263.

194 Lazarovici P, Fink D Jr: Heterologous upregulation of nerve growth factor-TrkA receptors in PC12 cells by pituitary adenylate cyclase-activating polypeptide (PACAP). Mol Cell Biol Res Commun 1999;2:97-102.
95 Rajagopal R, Chen ZY, Lee FS, Chao MV: Transactivation of Trk neurotrophin receptors by G-protein-coupled receptor ligands occurs on intracellular membranes. J Neurosci 2004;24:6650-6658.

196 El Zein N, Badran BM, Sariban E: The neuropeptide pituitary adenylate cyclase activating protein stimulates human monocytes by transactivation of the Trk/NGF pathway. Cell Signal 2007;19:152-162.

197 Lee FS, Rajagopal R, Kim AH, Chang PC, Chao MV: Activation of Trk neurotrophin receptor signaling by pituitary adenylate cyclase-activating polypeptides. J Biol Chem 2002;277:9096-9102.

198 Lee HW, Hahm SH, Hsu CM, Eiden LE: Pituitary adenylate cyclase-activating polypeptide regulation of vasoactive intestinal polypeptide transcription requires $\mathrm{Ca}^{2+}$ influx and activation of the serine/threonine phosphatase calcineurin. J Neurochem 1999;73:1769-1772.

199 Falktoft B, Georg B, Fahrenkrug J: Signaling pathways in PACAP regulation of VIP gene expression in human neuroblastoma cells. Neuropeptides 2009;43:387-396.

200 Tsutsumi M, Claus TH, Liang Y, Li Y, Yang L, Zhu J, Dela Cruz F, Peng X, Chen H, Yung SL, Hamren S, Livingston JN, Pan CQ: A potent and highly selective VPAC2 agonist enhances glucose-induced insulin release and glucose disposal: a potential therapy for type 2 diabetes. Diabetes 2002;51:1453-1460.

201 Robberecht P, Waelbroeck M, de Neef P, Camus JC, Vandermeers A, VandermeersPiret MC, Christophe J: Specific labelling by $\left[{ }^{125} \mathrm{I}\right]$ helodermin of high-affinity VIP receptors in rat liver membranes. FEBS Lett 1984; 172:55-58.

202 Yung SL, Dela Cruz F, Hamren S, Zhu J, Tsutsumi M, Bloom JW, Caudle M, Roczniak S, Todd T, Lemoine L, MacDougall $M$, Shanafelt AB, Pan CQ: Generation of highly selective VPAC2 receptor agonists by high throughput mutagenesis of vasoactive intestinal peptide and pituitary adenylate cyclaseactivating peptide. J Biol Chem 2003;278: 10273-10281.

203 Gourlet P, Vertongen P, Vandermeers A, Vandermeers-Piret MC, Rathe J, De Neef P, Waelbroeck M, Robberecht P: The long-acting vasoactive intestinal polypeptide agonist RO 25-1553 is highly selective of the VIP2 receptor subclass. Peptides 1997;18:403408. 